\title{
Cobalt Xanthate Thin Film with Chemical Bath Deposition
}

\author{
I. A. Kariper ${ }^{1}$ and T. Özpozan ${ }^{2}$ \\ ${ }^{1}$ Erciyes University, Education Faculty, 38039 Kayseri, Turkey \\ ${ }^{2}$ Erciyes University, Faculty of Art and Science, 38039 Kayseri, Turkey \\ Correspondence should be addressed to İ. A. Kariper; akariper@gmail.com
}

Received 15 March 2013; Accepted 8 May 2013

Academic Editor: Mengnan Qu

Copyright (C) $2013 \dot{I}$. A. Kariper and T. Özpozan. This is an open access article distributed under the Creative Commons Attribution License, which permits unrestricted use, distribution, and reproduction in any medium, provided the original work is properly cited.

\begin{abstract}
Cobalt xanthate thin films (CXTFs) were successfully deposited by chemical bath deposition, onto amorphous glass substrates, as well as on $\mathrm{p}$ - and n-silicon, indium tin oxide, and poly(methyl methacrylate). The structure of the films was analyzed by farinfrared spectrum (FIR), mid-infrared (MIR) spectrum, nuclear magnetic resonance (NMR), and scanning electron microscopy (SEM). These films were investigated from their structural, optical, and electrical properties point of view. Electrical properties were measured using four-point method, whereas optical properties were investigated via UV-VIS spectroscopic technique. Uniform distribution of grains was clearly observed from the photographs taken by scanning electron microscope (SEM). The transmittance was about $70-80 \%$ ( 4 hours, $50^{\circ} \mathrm{C}$ ). The optical band gap of the CXTF was graphically estimated to be $3.99-4.02 \mathrm{eV}$. The resistivity of the films was calculated as $22.47-75.91 \Omega \cdot \mathrm{cm}$ on commercial glass depending on film thickness and $44.90-73.10 \Omega \cdot \mathrm{cm}$ on the other substrates. It has been observed that the relative resistivity changed with film thickness. The MIR and FIR spectra of the films were in agreement with the literature analogues. The expected peaks of cobalt xanthate were observed in NMR analysis on glass. The films were dipped in chloroform as organic solvent and were analyzed by NMR.
\end{abstract}

\section{Introduction}

Cobalt xanthates are similar to hybrid materials, because they have an organic sulfide part and inorganic metal part as iron xanthate. These organometallic compounds have wide ranging properties such as optical, electrical, and magnetic characteristics [1-4]. It has been shown that these thin films show different properties such as an antibacterial agent, magnetic and semiconductor material, which allowed them to be used for data storage, solar cell production, and water purification [5-10]. Neither cobalt isopropyl xanthate thin films production nor their optical, electrical properties and structural analysis have been studied yet. These thin films and their bulk compounds may be useful in many areas, especially in solar cells. Chemical vapor deposition and physical vapor deposition are included among thin film deposition methods used to produce metal sulfide thin films $[5,11]$. These methods are expensive and need a variety of instruments unlike the chemical bath deposition method.

The aim of this paper was to produce cobalt xanthate thin film by chemical bath deposition method and to examine its structural, optical, and electrical properties. Metal xanthate complexes rapidly occur when the precipitate rises to the surface in chemical bath deposition. Moreover, due to the nature of organometallic thin films, it is difficult to analyze them. The metal xanthates thin films were produced with difficulty.

\section{Experimental}

2.1. Reagents. Isopropyl xanthate was synthesized first as described in the literature, and the stock solution of $0.1 \mathrm{M}$ was prepared. High purity reagents were used for all the prepared solutions. The stock solution was diluted each time when required. The other stock solution of iron nitrate salt was prepared from high purity compound (99.9\%, E. Merck, Darmstadt, Sigma Aldrich). All laboratory glassware and substrates were cleaned by soaking in diluted nitric acid and rinsing with alcohol and deionized water prior to use.

2.2. Synthesis of Isopropyl Xanthate. Isopropyl xanthate was synthesized by dissolving $3.74 \mathrm{~g}$ of $\mathrm{KOH}(0.067 \mathrm{~mol})$ in a mixture of $4.5 \mathrm{~mL} \mathrm{CS}_{2}, 6 \mathrm{~mL}$ isopropyl alcohol and $9 \mathrm{~mL}$ benzene and heated under a reflux condenser. The mixture was mixed 


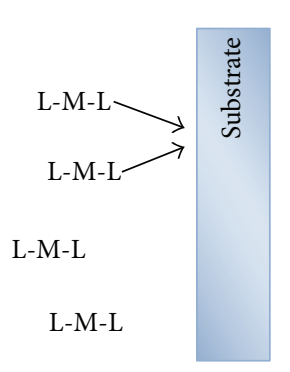

(a)

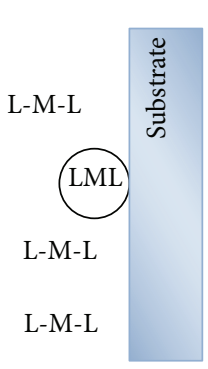

(b)

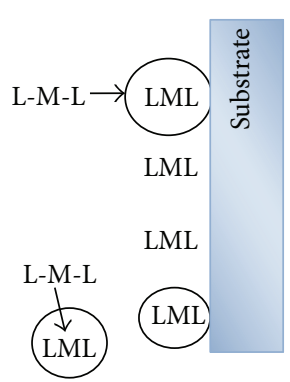

(c)

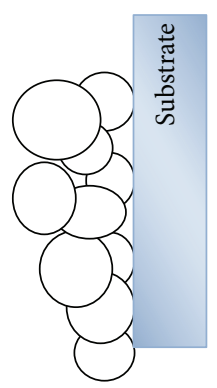

(d)

Figure 1: Probable steps related with complex formation (ion-ion mechanism). (a) Particles of L-M-L complexes are spread towards the substrate.(b) The complex is stuck to the substrate as an LML composite, still being in the solution. (c) LML grains grow with the formation of more complexes and absorption. (d) Grains form the film by sticking to each other (M: metal, L: ligand) [12].

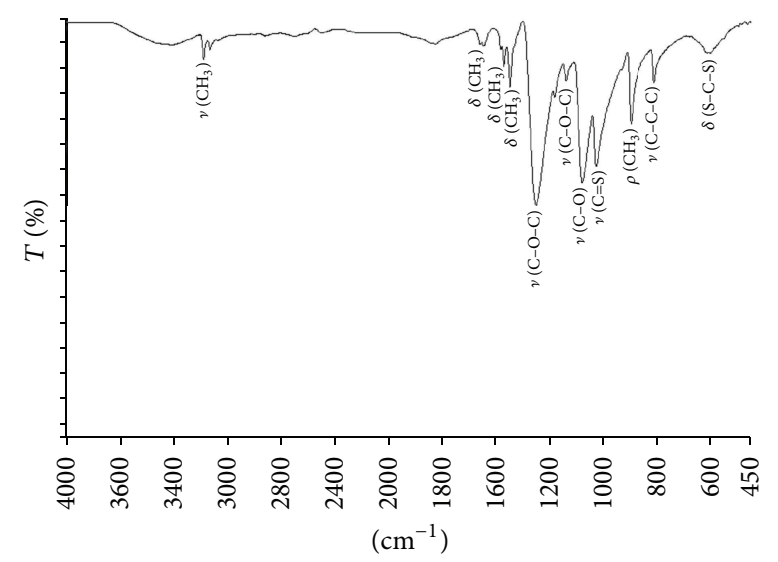

FIGURE 2: Cobalt xanthate thin film on glass substrate MIR spectrum.

for 20 minutes at $35^{\circ} \mathrm{C}$ and for 45 minutes at $45^{\circ} \mathrm{C}$. Then, it was mixed for 1 hour at $60^{\circ} \mathrm{C}$. Approximately 9 grams of the reaction product was then purified by rinsing with acetone and drying in the oven at $30^{\circ} \mathrm{C}$ for 48 hours [13-30].

2.3. Preparation of Films. Ten $\mathrm{mL}$ of $0.1 \mathrm{M}$ cobalt nitrate and $10 \mathrm{~mL}$ of $0.1 \mathrm{M}$ isopropyl xanthate were mixed in a beaker. The substrates were dipped into this chemical bath at required temperatures. As the result of ion-ion mechanism, CXTF was formed and was deposited on all the substrates. The films were deposited at different temperatures of 30,40 , and $50^{\circ} \mathrm{C}$, whereas $\mathrm{pH}$ of the bath was maintained between 6.50 . In addition, deposition time was changed from 4 to 7 hours at 40 and $50^{\circ} \mathrm{C}, 16-19$ hours at $30^{\circ} \mathrm{C}$. The thin films were cleaned in purified water and dried before their further examinations. The formation of the film is shown in detail in Figure 1.

2.4. Measurements. The vibrational spectrum of CXTF was recorded by Perkin Elmer Spectrum 400 spectrometer (TGS detector) with ATR. The scanning number was 10 and resolution was $4 \mathrm{~cm}^{-1}$. The ${ }^{1} \mathrm{H}-\mathrm{NMR}$ spectrum was measured by a Bruker $(400 \mathrm{MHz})$ spectrometer. The surface properties of all films were examined using EVO40-LEO computer controlled digital scanning electron microscope (SEM) with seconder

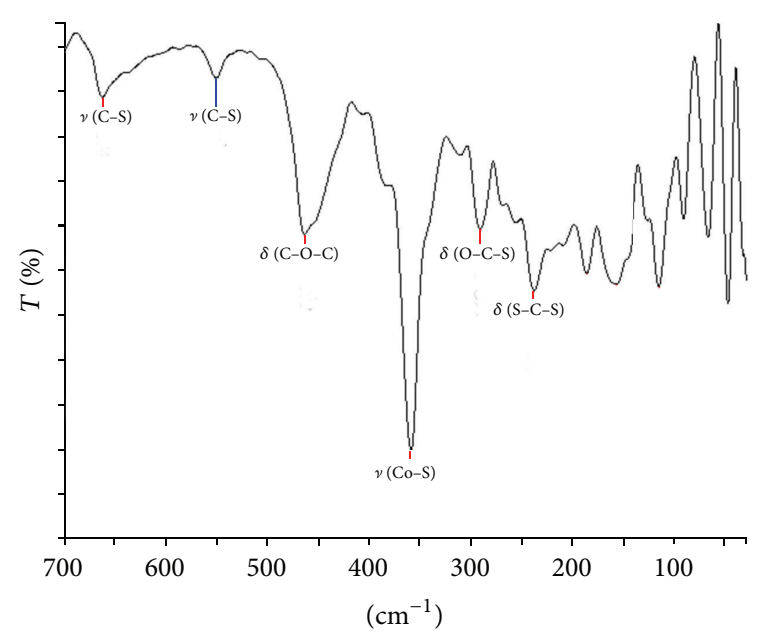

FIGURE 3: Cobalt xanthate thin film on glass substrate FIR spectrum.

electron detector. Electrical properties were measured using four-point measurements technique, and accordingly the resistivity was calculated. The film thicknesses were measured with atomic force microscopy (AFM). The optical measurements were conducted by a Hach Lange DR 5000 spectrophotometer at room temperature by placing an uncoated identical glass substrate in the reference beam. The optical spectra of the thin films were recorded in the wavelength range of $250-700 \mathrm{~nm}$.

\section{Results and Discussion}

We used the FIR, MIR, and ${ }^{1} \mathrm{H}-\mathrm{NMR}$ spectra of cobalt xanthate thin film on glass. The spectra are shown in Figures 2, $3,4,5$, and 6 .

Figure 1 illustrates that in the cobalt xanthate thin film,

(i) the $-\mathrm{OH}$ peak occurred at $3200-3600 \mathrm{~cm}^{-1}$,

(ii) the symmetric stretching vibration of the aliphatic groups $\left(-\mathrm{CH}_{3}\right)$ was seen at $2976-2932 \mathrm{~cm}^{-1}$,

(iii) the bending vibration of $-\mathrm{CH}_{3}$ was seen at $1448-1373-$ $1349 \mathrm{~cm}^{-1}$, 


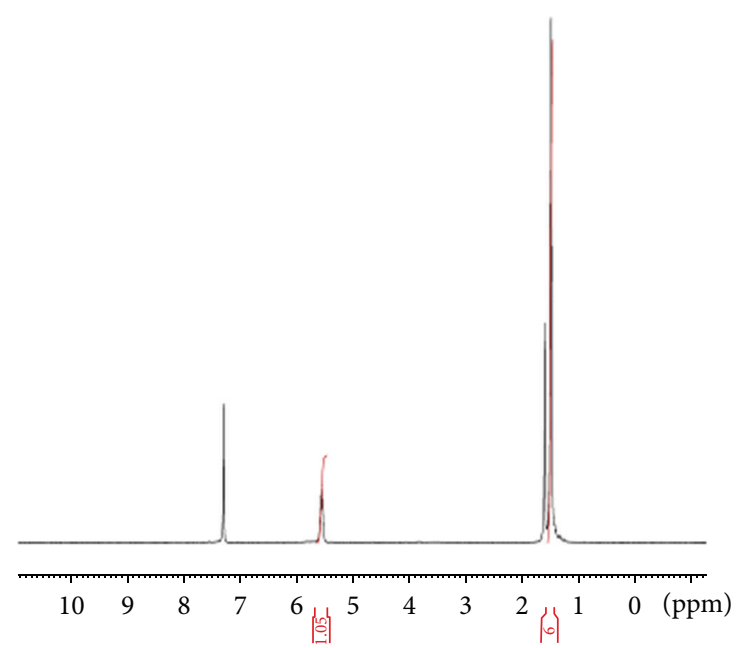

FIgURE 4: Cobalt xanthate thin film ${ }^{1} \mathrm{H}-\mathrm{NMR}$ at $0-10 \mathrm{ppm}$.

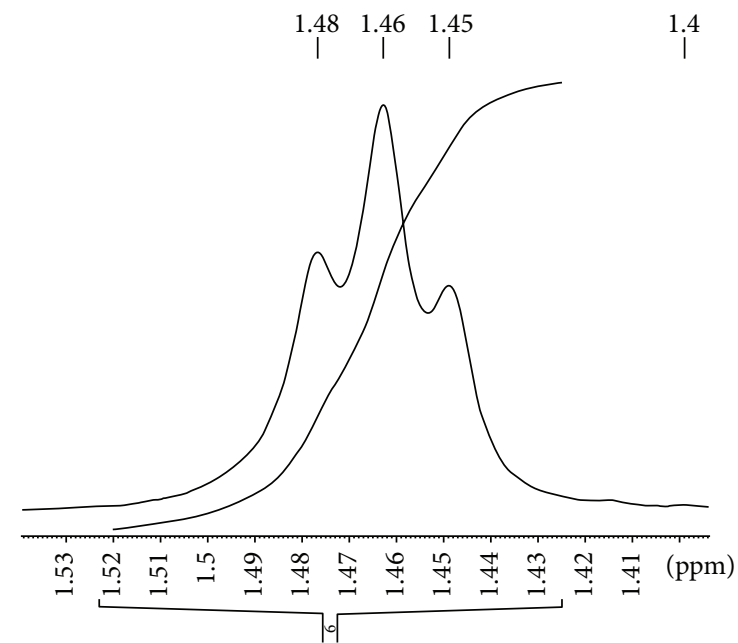

Figure 5: Cobalt xanthate thin film ${ }^{1} \mathrm{H}-\mathrm{NMR}$ at $1 \mathrm{ppm}$.

(iv) the asymmetric stretching of $\mathrm{C}-\mathrm{O}-\mathrm{C}$ at $1253-1182-$ $1141 \mathrm{~cm}^{-1}$,

(v) the symmetric stretching vibration of $-\mathrm{C}-\mathrm{O}$ at $1081 \mathrm{~cm}^{-1}$,

(vi) the stretching vibration of $-\mathrm{C}=\mathrm{S}$ at $1029 \mathrm{~cm}^{-1}$,

(vii) rocking vibration of $-\mathrm{CH}_{3}$ at $899 \mathrm{~cm}^{-1}$,

(viii) symmetric vibration of $-\mathrm{C}-\mathrm{C}-\mathrm{C}$ at $811 \mathrm{~cm}^{-1}$, and

(ix) symmetric stretching vibration of S-C-S at $602 \mathrm{~cm}^{-1}$.

In Figure 3, the stretching vibrations of $\mathrm{Co}-\mathrm{S}$ were observed at $359 \mathrm{~cm}^{-1}$, similar to the other functional groups of cobalt xanthate's organic parts [31-38]. We did not consider any measurements below $200 \mathrm{~cm}^{-1}$. Figure 3 illustrates that in the cobalt xanthate thin film,

(i) the vibration of $-\mathrm{C}-\mathrm{S}$ at $662-521 \mathrm{~cm}^{-1}$,

(ii) the bending vibration of $-\mathrm{C}-\mathrm{O}-\mathrm{C}$ at $463 \mathrm{~cm}^{-1}$,

(iii) the stretching vibration of $\mathrm{O}-\mathrm{C}-\mathrm{S}$ at $291 \mathrm{~cm}^{-1}$, and

(iv) the bending vibration of $\mathrm{S}-\mathrm{C}-\mathrm{S}$ at $238 \mathrm{~cm}^{-1}$.

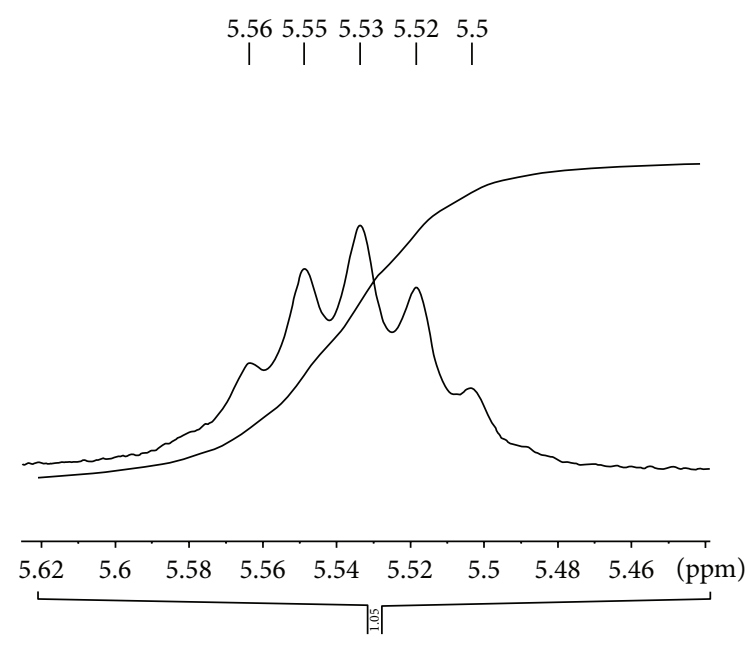

Figure 6: Cobalt xanthate thin film ${ }^{1} \mathrm{H}-\mathrm{NMR}$ at $5 \mathrm{ppm}$.

In the ${ }^{1} \mathrm{H}$-NMR spectrum (Figures 4-6), CXTF was dipped into a chloroform solution for spectrum analysis. The scanning number was 16 for all samples. The solvent peak (chloroform) was observed at $7.2 \mathrm{ppm}$, whereas trace concentration of the water peak was observed at $1.5 \mathrm{ppm}$ when the triplet peak of the $-\mathrm{CH}_{3}$ group occurred at 1.52 and $1.41 \mathrm{ppm}$. Since proton number was one, integration number was 1.05. The group of $-\mathrm{CH}$ NMR peaks was divided into five at between 5.50-5.60 due to neighboring $-\mathrm{CH}_{3}$ groups, and the integration number was 1.05 . The $-\mathrm{CH}$ group had an oxygen atom as a neighbor which caused a decreased electron shielding, so its peak was observed in the low area [39-41]. No impurities were observed in the spectra. The $1 \mathrm{ppm}$ peak was expected to split into a double peak, but actually it was divided into triplet peak. This meant that

(i) the rotation of the isopropyl groups can be obstructed, and the methyl groups give doublet-doublet resonance,

(ii) the isopropyl groups can be bonded to different cobalt shapes, and the methyl groups give doublet-doublet resonance,

(iii) magnetic properties of cobalt atom can also be affected by the NMR spectrum, which is come together doublet-doublet peak.

The doublet peaks can be combined with each other, thus we saw a triplet peak [42].

The transmittance $(T)$ and absorbance $(A)$ for CXTF can be used for the calculation of reflectance $(R)$ from the following expression [43]:

$$
T=(1-R)^{2} e^{-A} .
$$

Transmittance and absorbance measurements were performed at room temperature in the range of $300-1100 \mathrm{~nm}$. The films were deposited at different deposition temperatures and deposition times as shown in Figures 7, 8, and 9. The transmittance change with changing deposition times and deposition temperatures can be seen from the curves. The optimum 


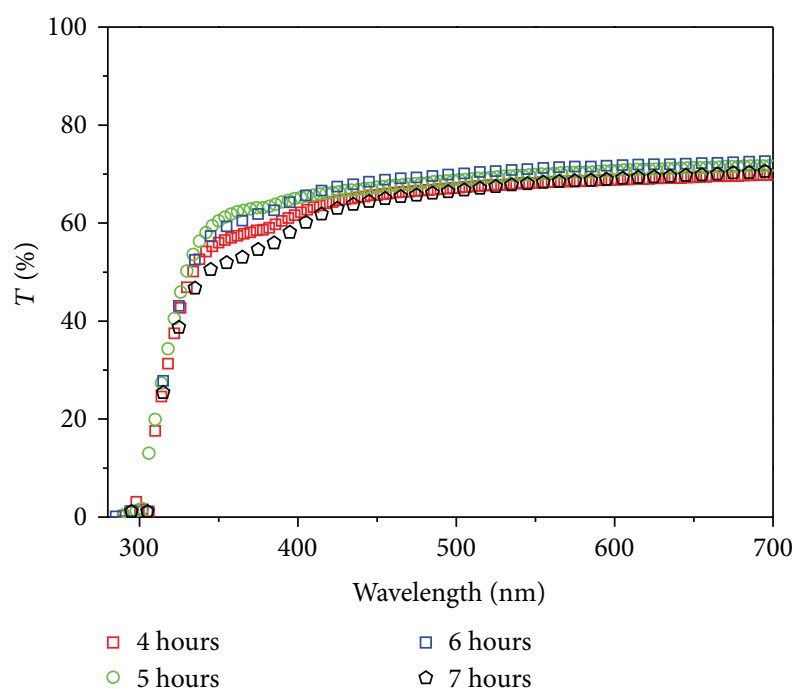

Figure 7: Change of $\% T$ and $\% R$ with wavelength at various deposition time $\left(t=50^{\circ} \mathrm{C}\right)$.

values for deposition time and temperature were selected as 4 hours at $50^{\circ} \mathrm{C}$, respectively ( $70 \%$ transmittance).

The highest deposition temperature and time were taken as $50^{\circ} \mathrm{C}$ and 19 hours (at $30^{\circ} \mathrm{C}$ ) for upper limit of the parameters, respectively. Metal xanthates are known to decompose beyond these limits [36]. Cobalt xanthates, in a similar way, decomposed at $60^{\circ} \mathrm{C}$ and 21 hour of deposition time to give iron oxide, oxide chloride, or sulfide as decomposition product in this study. The cobalt xanthate decomposed into cobalt oxide or sulfide above $50^{\circ} \mathrm{C}$ and 19 hours.

The refractive index and extinction coefficient for the films are given by the following equations [43]:

$$
\begin{gathered}
n=\frac{(1+R)}{(1-R)}+\sqrt{\frac{4 R}{(1-R)^{2}}-k^{2},} \\
k=\frac{\alpha \lambda}{4 \prod} .
\end{gathered}
$$

The refractive index was not regularly affected by deposition temperatures at $30,40,50^{\circ} \mathrm{C}$, and its values were reported as $1.80,2.60$, and 1.80 in Figure 10. The refractive index was sputtered at $40^{\circ} \mathrm{C}$. Moreover, the extinction coefficient behaved in the same way and the extinction coefficients were, respectively, $0.023,0.025$, and 0.082 at $30,40,50^{\circ} \mathrm{C}$ (in $550 \mathrm{~nm}$ wavelength). The $n-k$ graphic shows anomalous dispersion. According to literature, this anomalous behavior is due to the resonance effect between the incidental electromagnetic radiation and the electrons polarization, which leads to the electron coupling in the structure of the oscillating electric field [44]. The optic band gap energy (Eg) was determined from the absorption spectra of the films using the following relation [43-48]:

$$
(\alpha h v)=A(h v-E g)^{n},
$$

where $A$ is a constant, $\alpha$ is the absorption coefficient, $h \nu$ is the photon energy, and $n$ is a constant, which is equal to $1 / 2$ for

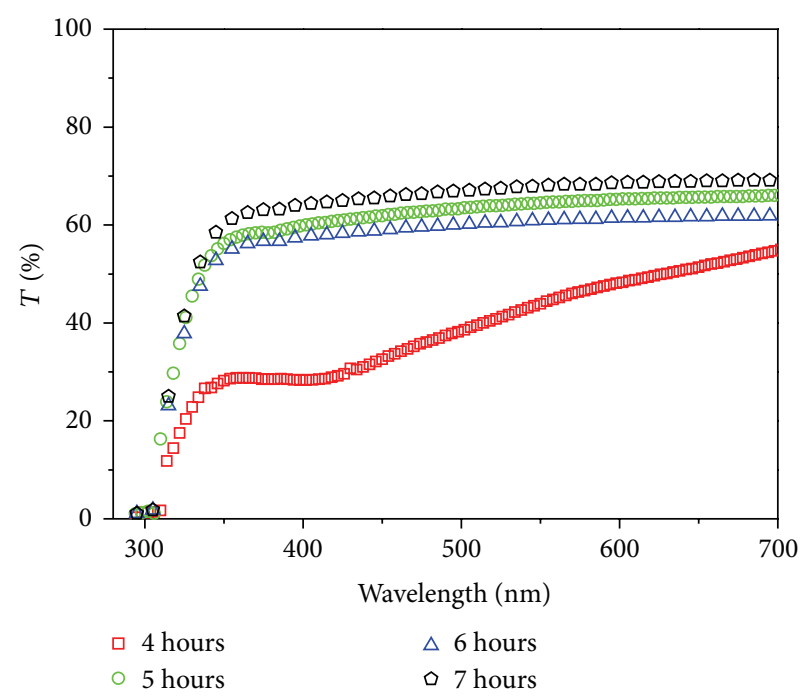

FIGURE 8: Change of $\% T$ and $\% R$ with wavelength at various deposition time $\left(t=40^{\circ} \mathrm{C}\right)$.

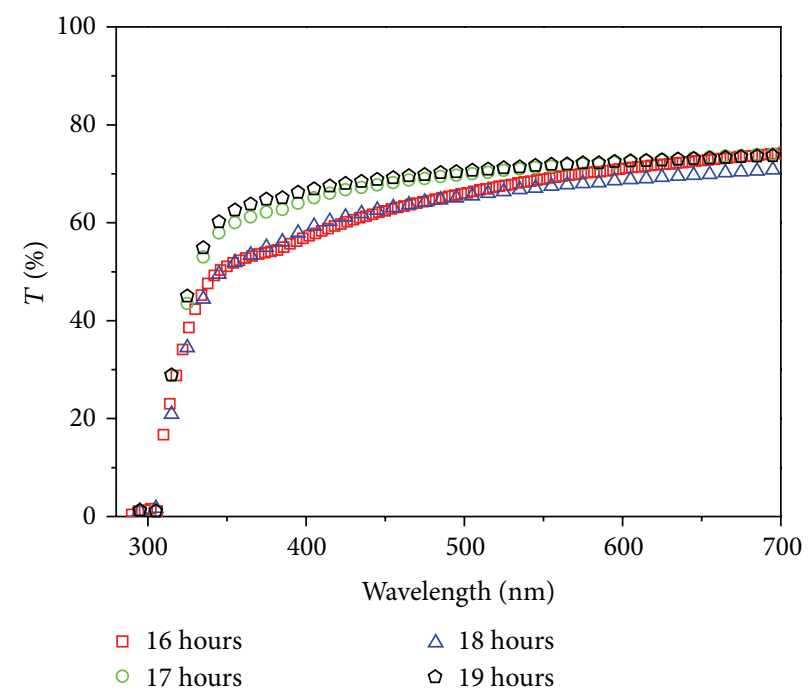

FIgURE 9: Change of $\% T$ and $\% R$ with wavelength at various deposition time $\left(t=30^{\circ} \mathrm{C}\right)$.

the direct band gap semiconductor. The plot of $(\alpha h v)^{2}$ versus $h v$ is illustrated in Figure 11.

The band gaps (Eg) of the films changed as 3.98, 3.99, and 4.01 in Figure 11. Film thickness was increased with deposition temperature, whereas the band gap of the films was not decreased with film thickness. Both electrical and optical bandwidths of a material are correlated with the magnitude of columbic interactions. To be more precise, the size of atoms and electronegativity values are the two most important factors, affecting bandwidth. Bandwidth of a material is expected to get higher when the atoms get smaller, bonds getting stronger, and with higher electronegativity of the atoms. Although there are some exceptions, nitrides and oxides, which are the elements from III-V groups of periodic table, are generally known with their high optic band ranges. 


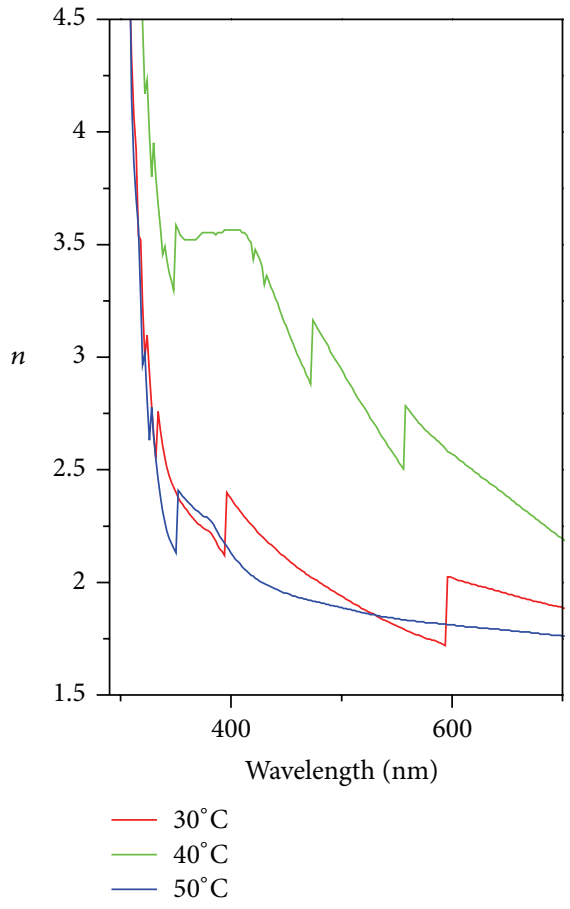

(a)

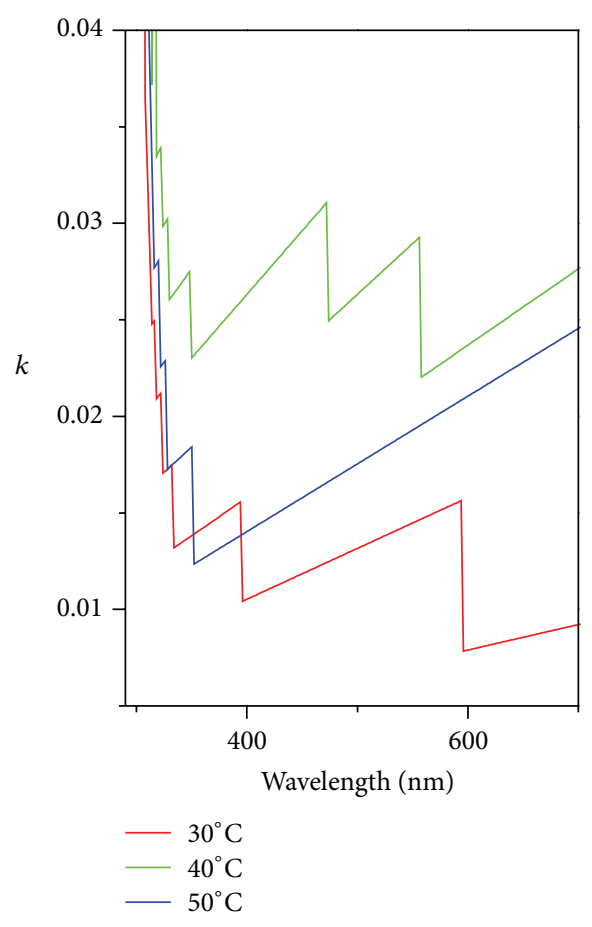

(b)

FIGURE 10: $n-k$ graphic according to deposition temperature.

The high optic bandwidth of the organometallic compound used in our study is in line with the literature, since it is formed by small atoms with high electronegativity [49].

It was found that the film thicknesses were not increased nearly linearly with increasing deposition temperature whereas the band gap of the films decreased with increasing film thickness as expected. Similarly, resistivity increased with film thicknesses which was contradictory to the literature [50]. The film thickness of the films is shown at Figure 12, according to deposition time.

The resistivity of the films was determined by four-point measurements of the films using the following relation [51]:

$$
\rho=\frac{\prod W}{\ln 2} \frac{V}{I} \quad(W \ll s),
$$

where $W$ is film thickness, $V$ is the voltage, $I$ is the current, and $s$ is the distance between the probes. The resistivity was measured in dark, at room temperature. In the measurements, the distance of the probes was in millimeter, whereas the film thickness was in nanometer scale.

The resistivities of the films were measured as 22.47, 42.71, and $75.91 \Omega \cdot \mathrm{cm}$ for the film thicknesses 198.14, 267.15, and $454.07 \mathrm{~nm}$, respectively. The resistivity of the films deposited increased with the film thickness as can be seen from the plot of film thickness versus resistivity (Figure 13). Although Moualkia et al. and Kasap et al. found that the film thicknesses between $250-900 \mathrm{~nm}$ were slightly affected by the resistivity of the film, the resistivity of cobalt xanthate increased with the film thickness $[48,50]$. It is a known fact that the aliphatic groups in the structure increase the resistance, they are not conductive. Thus, they are causing an increase on the resistance with the increase of the film thickness.

Thin fims were also produced on $n$-silicium, $p$-silicium, poly(methyl methacrylate), and indium tin oxide as different substrates in this work. The film resistivity on these substrates was found to be different than commerical glass studied previously. The resistivities of the poly (methyl methacrylate) (PMM), indium tin oxide (ITO), n-silicon (n-Si), and psilicon ( $\mathrm{p}$-Si) substrates were measured as $67.15,50.98,44.90$, and $73.10 \Omega \cdot \mathrm{cm}$ at the optimized parameters of deposition time and temperature, respectively (Figure 14). It was found that CXTF on $\mathrm{p}-\mathrm{Si}$ substrate had the highest resistivity, whereas the resistivity of the $\mathrm{n}$-Si was the lowest [52-54]. It is a well-known fact that these kinds of materials are stuck to the surface with $\pi$-bonds or with idle electrons of electronegative atoms [6]. When such a material is deposited on $\mathrm{n}-\mathrm{Si}$, which is rich on electrons, the electron doublets of these bonds as well as idle doublets will apply a tension to the material; thus electron transmission between the substrate and thin film will be easier. So the resistance will decrease and the conductivity will increase. In the literature, there are examples about the impact of substrates on the resistance [55].

Figures 15(a) and 15(b) show SEM photos of cobalt xanthate thin film. It is given strange exposure. At 5 and $10 \mu \mathrm{m}$, SEM photo of cobalt xanthate thin film was dispersed like biologic cells. The grains were resembling cancer cells in micron scale. It was assumed that the grains formed colonies. Spaces appeared very frequently at $10 \mu \mathrm{m}$ scale. The grains scattered very much. Any connection did not appear between the cells. These large spaces affect the homogeneity of the thin films, 


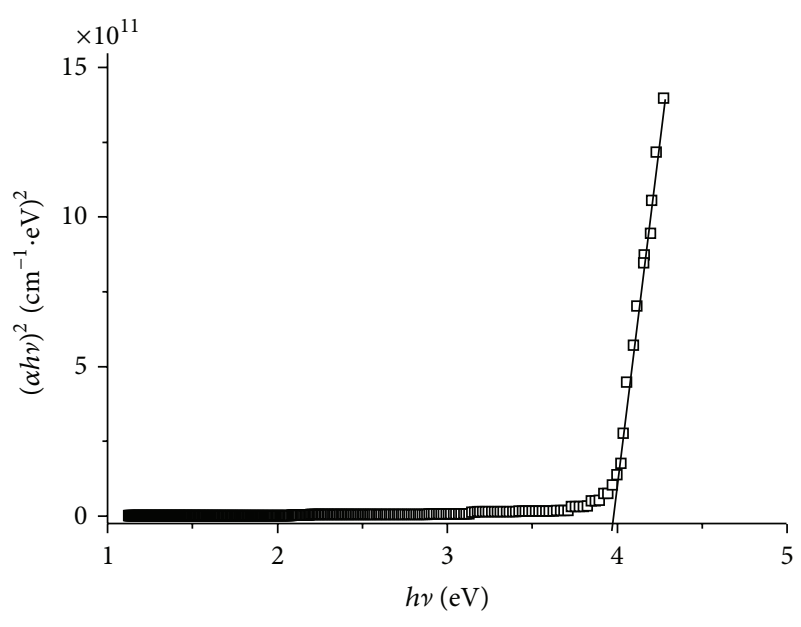

$\square 30^{\circ} \mathrm{C}$

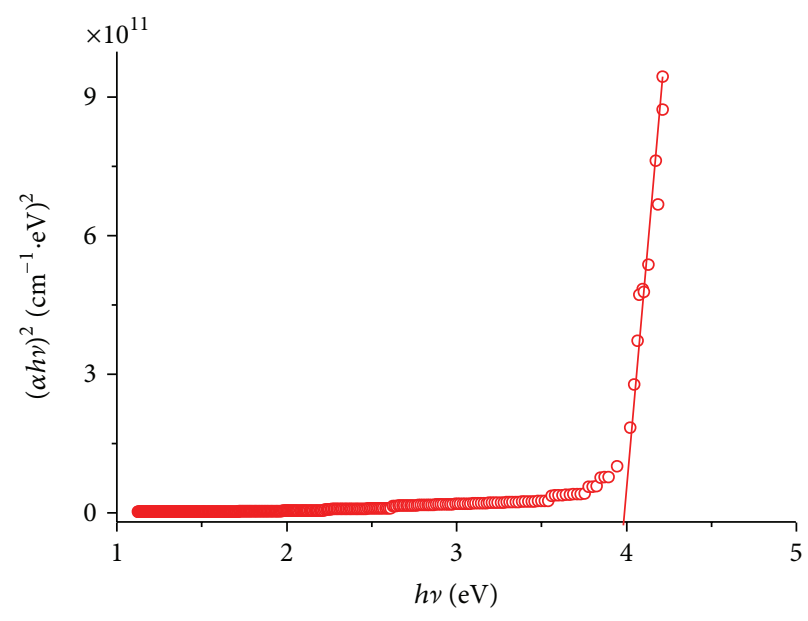

$40^{\circ} \mathrm{C}$

(a)

(b)

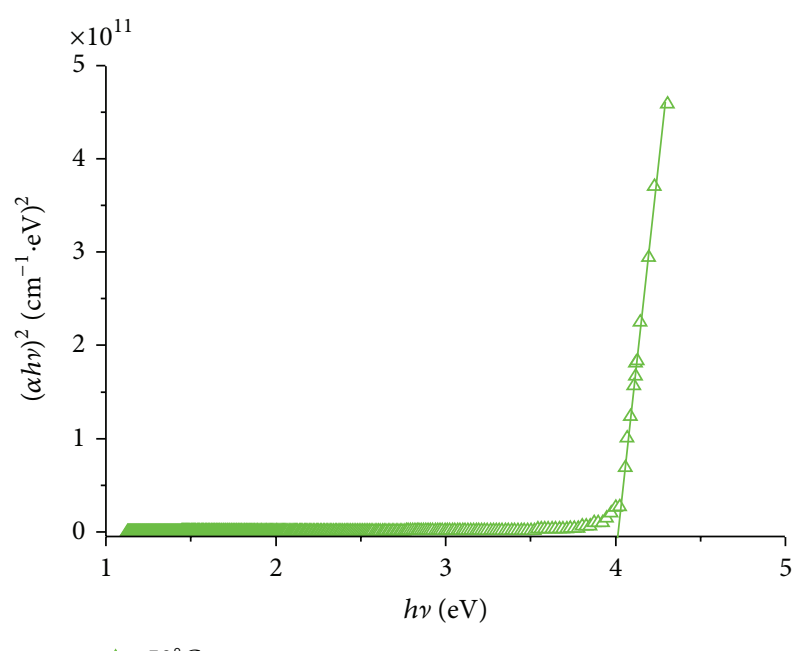

(c)

FIGURE 11: Plot of $(\alpha h \nu)^{2}$ versus $h v$ in different deposition temperatures.

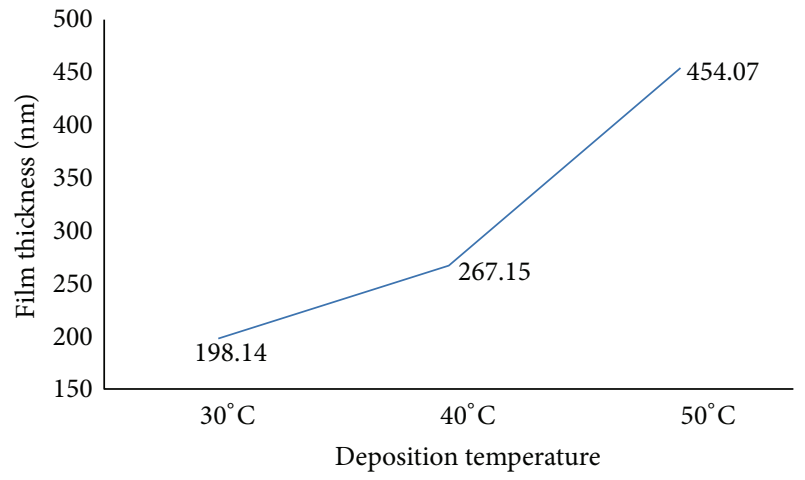

FIGURE 12: Film thickness-deposition temperature.

which might be the reason of their high resistivity. Also it may be the reason of anomalous behaviors of optical properties.

The elemental analysis results were calculated using the ratio of sulfide and cobalt according to EDX data in Figure 16.

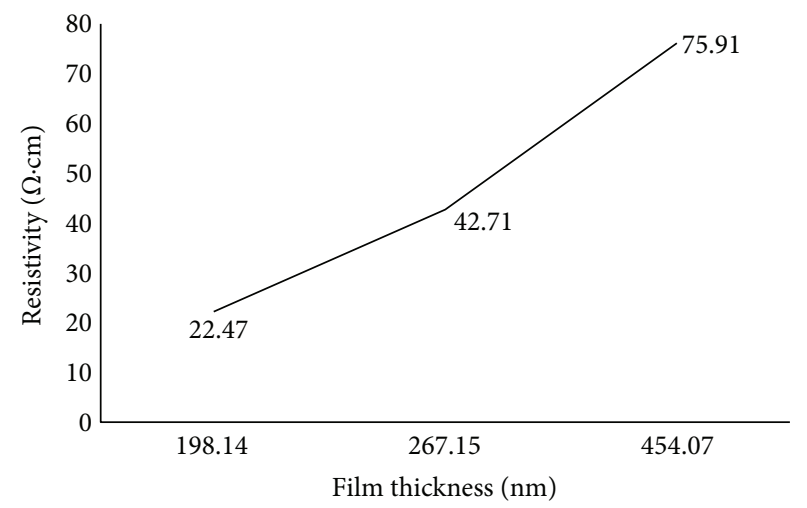

FIgURE 13: Resistivity—film thickness.

The ratio of sulfide and cobalt changed with deposition temperature. The ratios of sulfide and cobalt in different deposition temperatures were $1.262,1.776$, and 2.112 . In a cobalt 


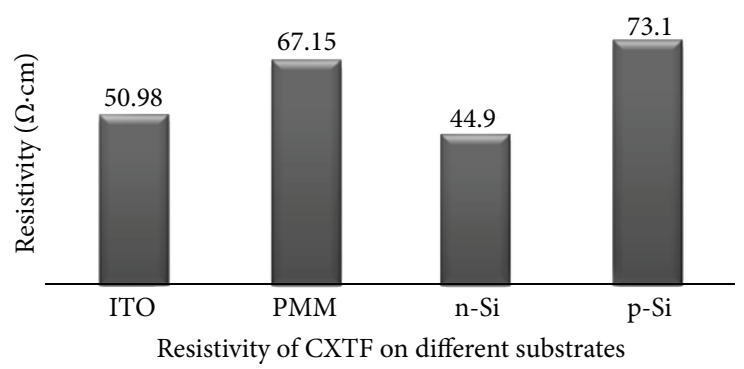

FIGURE 14: Resistivity of CXTF on different substrates.

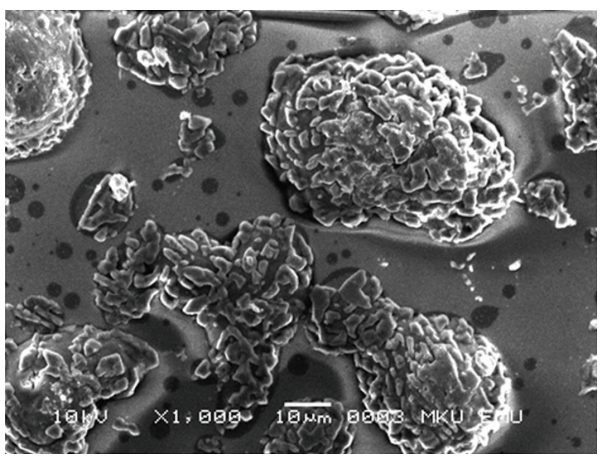

(a)

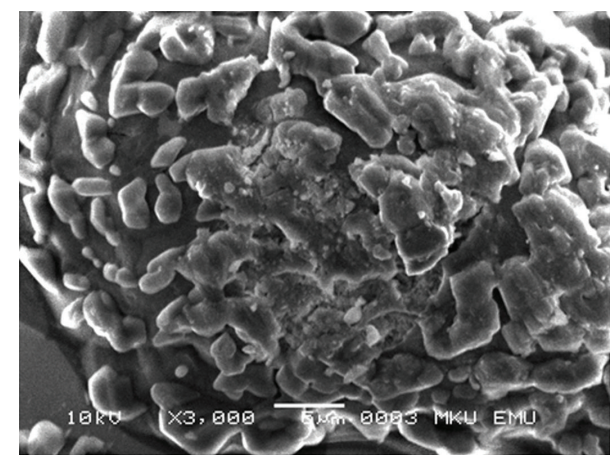

(b)

Figure 15: (a) Cobalt xanthate thin film on glass substrate $(10 \mu \mathrm{m})$. (b) Cobalt xanthate thin film on glass substrate $(5 \mu \mathrm{m})$.

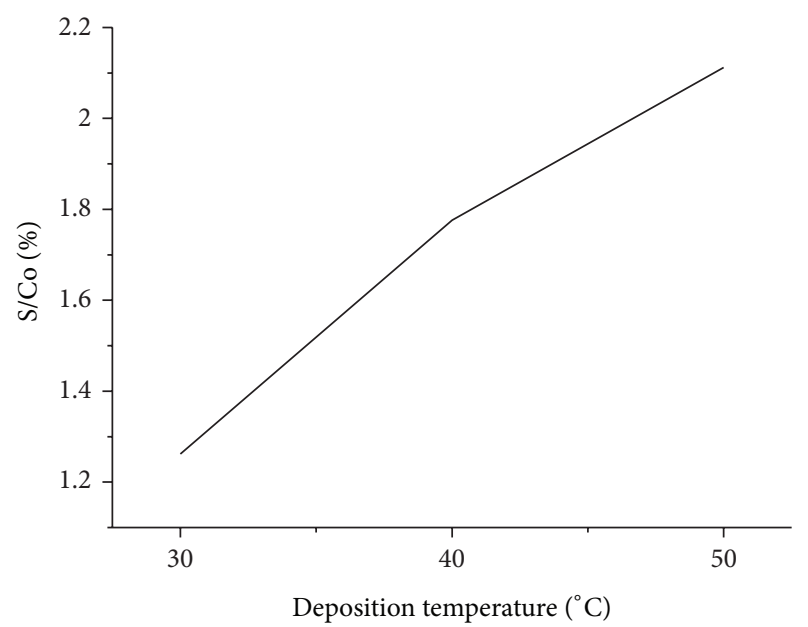

FIGURE 16: Sulfide and cobalt elemental ratio according to deposition temperature.

xanthate molecule, the theoretical ratio of the sulfide and cobalt is approximately 3.255. The elemental results were closer to the theoretical value at $50^{\circ} \mathrm{C}$ (Co-tris isopropyl xanthate). This shows that the cobalt cation bonds to the three xanthate molecule, as per the literature [37].

\section{Conclusion}

Cobalt isopropyl xanthate thin film was prepared first time on glass, poly(methyl methacrylate), indium tin oxide, n-silicon, and p-silicon substrate via ion-ion mechanism. The optimum parameters were determined to be 4 hours and $50^{\circ} \mathrm{C}$ for the deposition time and the temperature. The variations of some chemical properties at different deposition temperatures, such as $30,40,50^{\circ} \mathrm{C}$, were examined, and the following outputs have been obtained:

(i) refractive indexes: 1.80, 2.60, and 1.80 (550 nm wavelength) at $30,40,50^{\circ} \mathrm{C}$, respectively,

(ii) extinction coefficients: $0.023,0.025$, and 0.082 at 30 , $40,50^{\circ} \mathrm{C}$, respectively,

(iii) band gaps (Eg) of the films: 4.01, 3.99, and $4.02 \mathrm{eV}$ at $30,40,50^{\circ} \mathrm{C}$, respectively,

(iv) film thicknesses were changed between 198.14$454.07 \mathrm{~nm}$ when temparature has been increased from 30 to $50^{\circ} \mathrm{C}$,

(v) resistivities of the films: $22.47,42.71$, and $75.91 \Omega \cdot \mathrm{cm}$ for the film thicknesses $198.14,267.15$, and $454.07 \mathrm{~nm}$, respectively,

(vi) the resistivities of the poly(methyl methacrylate) (PMM), indium tin oxide (ITO), n-silicium ( $\mathrm{n}-\mathrm{Si}$ ) and $\mathrm{p}$-silicium ( $\mathrm{p}-\mathrm{Si}$ ), substrates were measured as $67.15,50.98,44.90$, and $73.10 \Omega \cdot \mathrm{cm}$ at the optimum deposition time and temperature.

SEM images of the thin films gave insight about their resistivity and refractive index. It can be seen that the film deposited on $\mathrm{n}$-Si had lower resistivity than other ones. Although further investigation is needed for this new thin film, it seems to be a material which may be very useful for solar cells, dedectors, or sensors. 


\section{Acknowledgment}

This study was extracted from Ph.D. thesis and was supported by Erciyes University. The authors are grateful for the technical and laboratory support of Erciyes University.

\section{References}

[1] F. Lisdat, R. Dronov, H. Möhwald, F. W. Scheller, and D. G. Kurthw, "Self-assembly of electro-active protein architectures on electrodes for the construction of biomimetic signal chains," Chemical Communications, vol. 21, no. 3, pp. 274-283, 2009.

[2] S. Liu, D. G. Kurth, and D. Volkmer, "Polyoxometalates as pHsensitive probes in self-assembled multilayers," Chemical Communications, no. 9, pp. 976-977, 2002.

[3] Z. Takáts, J. M. Wiseman, B. Gologan, and R. G. Cooks, “Electrosonic spray ionization. A gentle technique for generating folded proteins and protein complexes in the gas phase and for studying ion-molecule reactions at atmospheric pressure," Analytical Chemistry, vol. 76, no. 14, pp. 4050-4058, 2004.

[4] G. Ramírez, M. C. Goya, L. Mendoza, B. Matsuhiro, M. Isaacs, and Y. Y. Chen, "Iron porphyrin-modified electrodes: influence of the method of modification on the stability and electroactivity in oxidation of sulfite or hydrogensulfite in ethanol-water solutions," Journal of Coordination Chemistry, vol. 62, pp. 27822791, 2009.

[5] H. J. Gao, Z. X. Bian, H. Y. Chen, Z. Q. Xue, and S. J. Pang, "A new type of organometallic system for high density data storage by scanning tunneling microscopy," Chemical Physics Letters, vol. 272, no. 5-6, pp. 459-462, 1997.

[6] J. C. F. Rodríguez-Reyes and A. V. Teplyakov, "Chemistry of organometallic compounds on silicon: the first step in film growth," Chemistry, vol. 13, no. 33, pp. 9164-9176, 2007.

[7] M. Grassi, D. A. W. Soares, A. A. A. De Queiroz, A. H. A. Bressiani, and J. C. Bressiani, "Organometallic chemical vapor deposition of compound semiconductors," Materials Science and Engineering B, vol. 112, no. 2-3, pp. 179-181, 2004.

[8] R. A. Fischer, J. Weiß, and W. Rogge, "Organometallic chemical vapour deposition of cobalt/indium thin films using the single-molecule precursors $\left[(\mathrm{CO})_{4} \mathrm{Co}\right]_{a} \mathrm{InR}_{3-a}(\mathrm{R}=$ $\left.\mathrm{CH}_{2} \mathrm{CH}_{2} \mathrm{CH}_{2} \mathrm{NMe}_{2} ; \mathrm{a}=1-3\right)$," Polyhedron, vol. 17, no. 7, pp. 1203-1210, 1998.

[9] Y. Jeong, J. Lee, S. Ha, and S. H. Kim, "Fabrication of cobaltorganic composite thin film via plasma-enhanced chemical vapor deposition for antibacterial applications," Thin Solid Films, vol. 517, no. 9, pp. 2855-2858, 2009.

[10] P. L. Musetha, The use of metal complexes to deposite metals calconide thin films and nanoparticles [Ph.D. thesis], University of Zululand, Richards Bay, South Africa, 2006.

[11] M. L. Hitchman and K. H. Jensen, Chemical Vapor Deposition: Principles and Applications, Academic Press, San Diego, Calif, USA, 1993.

[12] G. Hodes, Chemical Solution Deposition of Semiconductor Films, Merker Dekker, New York, NY, USA, 2003.

[13] J. A. Ruffle, G. J. Knighton, and E. Y. Spencer, "Process for the production of sodium isopropyl xanthate," Canadian Intellectual Property Office, CA, 489807, 1953.

[14] H. Wilhelm, "Process for preparing xanthates," United States Patent Office, 2024925, 1935.

[15] H. Wilhelm, "Preparing of making xanthates," United States Patent Office, 2024924, 1935.
[16] J. C. McCool, "Method of preparing alkali metal xanthates," United States Patent Office, 2678939, 1954.

[17] H. Wilhelm, "Process of manufacturing sodium xanthates," United States Patent Office, 1701264, 1929.

[18] A. López Valdivieso, A. A. Sánchez López, C. Ojeda Escamilla, and M. C. Fuerstenau, "Flotation and depression control of arsenopyrite through $\mathrm{pH}$ and pulp redox potential using xanthate as the collector," International Journal of Mineral Processing, vol. 81, no. 1, pp. 27-34, 2006.

[19] J. D. Miller, J. Li, J. C. Davidtz, and F. Vos, "A review of pyrrhotite flotation chemistry in the processing of PGM ores," Minerals Engineering, vol. 18, no. 8, pp. 855-865, 2005.

[20] J. Rubio, F. Capponi, R. T. Rodrigues, and E. Matiolo, "Enhanced flotation of sulfide fines using the emulsified oil extender technique," International Journal of Mineral Processing, vol. 84, no. 1-4, pp. 41-50, 2007.

[21] A. Fehér, E. Urbán, I. Erős, P. Szabó-Révész, and E. Csányi, "Lyotropic liquid crystal preconcentrates for the treatment of periodontal disease," International Journal of Pharmaceutics, vol. 358, pp. 23-26, 2008.

[22] G. C. Armitage, "Periodontal diagnoses and classification of periodontal diseases," Periodontology 2000, vol. 34, pp. 9-21, 2004.

[23] U. Bertram and R. Bodmeier, "Parameters affecting the drug release from in situ gelling nasal inserts," European Journal of Pharmaceutics and Biopharmaceutics, vol. 63, no. 3, pp. 310-319, 2006.

[24] E. Pellizzeti and E. Pramauro, "Analytical applications of organized molecular assemblies," Analytica Chimica Acta, vol. 169, pp. 1-29, 1985.

[25] C. D. Stalikas, "Micelle-mediated extraction as a tool for separation and preconcentration in metal analysis," Trends in Analytical Chemistry, vol. 21, no. 5, pp. 343-355, 2002.

[26] E. Pramauro and A. B. Prevot, "Solubilization in micellar systems. Analytical and environmental applications," Pure and Applied Chemistry, vol. 67, pp. 551-559, 1995.

[27] J. L. Manzoori and A. Bavili-Tabrizi, "Cloud point preconcentration and flame atomic absorption spectrometric determination of $\mathrm{Cd}$ and $\mathrm{Pb}$ in human hair," Analytica Chimica Acta, vol. 470, no. 2, pp. 215-221, 2002.

[28] M. E. F. Laespada and J. L. Perez, "Micelle-mediated methodology for the preconcentration of uranium prior to its determination by flow injection "' Analyst, vol. 118, pp. 209-212, 1993.

[29] M. Ghaedi, "Selective and sensitized spectrophotometric determination of trace amounts of $\mathrm{Ni}(\mathrm{II})$ ion using $\alpha$-benzyl dioxime in surfactant media," Spectrochimica Acta Part A, vol. 66, pp. 295-301, 2007.

[30] G. D. L. Paleologos, S. M. Tzouwara-Karaynni, and M. T. Karayanis, "Micelle mediated methodology for the determination of free and bound iron in wines by flame atomic absorption spectrometry," Analytica Chimica Acta, vol. 458, no. 1, pp. 241248, 2002.

[31] D. E. Zelmon, Z. Gebeyehu, D. Tomlin, and T. M. Cooper, "Investigation of transition metal-xanthate complexes for nonlinear optical applications," in Proceedings of the MRS Spring Symposium, pp. 395-400, April 1998.

[32] I. Haiduc, R. F. Semeniuc, M. Campian, V. C. Kravtsov, Y. A. Simonov, and J. Lipkowski, "The reaction of nickel(II) xanthates with tetraphenyldiphosphinoethane (dppe) revisited. Formation and crystal structures of $\mathrm{Ni}_{3} \mathrm{~S}_{2}\left(\mathrm{~S}_{2} \mathrm{COR}\right)_{2}$ (dppe) $(\mathrm{R}=\mathrm{Me}$, Et; dppe $\left.=\mathrm{Ph}_{2} \mathrm{PCH}_{2} \mathrm{CH}_{2} \mathrm{PPh}_{2}\right)$ at room temperature and of 
$\mathrm{Ni}\left(\mathrm{S}_{2} \mathrm{CO}\right)(\mathrm{dppe})$ at $150 \mathrm{~K}$, Polyhedron, vol. 22, no. 21, pp. 2895$2900,2003$.

[33] E. Erdik, M. Obalı, N. Yüksekışık, A. Öktemer, and T. Pekel, Denel Organik Kimya. Gazi Kitapevi, Ankara, Turkey, 4 edition, 2007.

[34] N. Zohir, M. Bouhenguel, and A. E. Djebaili, "Synthesis and structural characterization of xanthate (KEX) in sight of their utilization in the processe s of sulphides flotation," Journal of Minerals and Materials Characterization and Engineering, vol. 8, no. 6, pp. 469-477, 2009.

[35] M. L. Shankaranarayana and C. C. Patel, "Infrared spectra and the structures of xanthates and dixanthogens," Canadian Journal of Chemistry, vol. 39, no. 8, pp. 1633-1637, 1961.

[36] D. Fornasiero, M. Montalti, and J. Ralston, "Kinetics of adsorption of ethyl xanthate on pyrrhotite: in situ UV and infrared spectroscopic studies," Journal of Colloid And Interface Science, vol. 172, no. 2, pp. 467-478, 1995.

[37] G. W. Watt and B. J. McCormick, "The infrared spectra and structure of transition metal xanthates," Spectrochimica Acta, vol. 21, no. 4, pp. 753-761, 1965.

[38] S. J. Cristol and D. G. Seapy, "New procedure for the transformation of alcohols to alkyl halides via xanthate esters and freeradical intermediates," Journal of Organic Chemistry, vol. 47, no. 1, pp. 132-136, 1982.

[39] A. V. Ivanov, "Copper(II) and Nickel(II) alkylxanthate complexes $\left(\mathrm{R}=\mathrm{C}_{2} \mathrm{H}_{5}, \mathrm{i}-\mathrm{C}_{3} \mathrm{H}_{7}, \mathrm{i}-\mathrm{C}_{4} \mathrm{H}_{9}, \mathrm{~s}-\mathrm{C}_{4} \mathrm{H}_{9}\right.$, and $\left.\mathrm{C}_{5} \mathrm{H}_{11}\right)$ : EPR and solid-State ${ }^{13} \mathrm{C}$ CP/MAS NMR Studies," Russian Journal of Coordination Chemistry, vol. 30, no. 7, pp. 480-485, 2004.

[40] H. Taş, Coordination Polymerization of Cyclic Ethers by Metal Xanthates and Carbamates, Yüksek Lisans Tezi, ODTU, Polimer Bilimi ve Teknolojisi Bölümü, Ankara, Turkey, 2003.

[41] G. A. Soomro, G. A. Shar, and M. I. Bhanger, "Spectrophotometric determination of copper(II) and palladium(II) complexes with isoamylxanthate in micellar media of SDS/Tween 80," Journal of the Chemical Society of Pakistan, vol. 10, no. 2, pp. 143-147, 2004.

[42] M. Balci, Basic ${ }^{1} H$ - and ${ }^{13} C$ - NMR Spectroscopy, Elsevier, 2005.

[43] N. Benramdane, W. A. Murad, R. H. Misho, M. Ziane, and Z. Kebbab, "A chemical method for the preparation of thin films of $\mathrm{CdO}$ and $\mathrm{ZnO}$," Materials Chemistry and Physics, vol. 48, no. 2, pp. 119-123, 1997.

[44] A. A. M. Farag, M. Cavas, F. Yakuphanoglu, and F. M. Amanullah, "Photoluminescence and optical properties of nanostructure $\mathrm{Ni}$ doped $\mathrm{ZnO}$ thin films prepared by sol-gel spin coating technique," Journal of Alloys and Compounds, vol. 509, no. 30, pp. 7900-7908, 2011.

[45] J. Santos-Cruz, G. Torres-Delgado, R. Castanedo-Perez, C. I. Zúñiga-Romero, and O. Zelaya-Angel, "Optical and electrical characterization of fluorine doped cadmium oxide thin films prepared by the sol-gel method," Thin Solid Films, vol. 515, no. 13, pp. 5381-5385, 2007.

[46] F. Liu, Y. Lai, J. Liu et al., "Characterization of chemical bath deposited CdS thin films at different deposition temperature," Journal of Alloys and Compounds, vol. 493, no. 1-2, pp. 305-308, 2010.

[47] B. Pejova, I. Grozdanov, and A. Tanusevski, "Optical and thermal band gap energy of chemically deposited bismuth(III) selenide thin films," Materials Chemistry and Physics, vol. 83, no. 2-3, pp. 245-249, 2004.

[48] H. Moualkia, S. Hariech, and M. S. Aida, "Structural and optical properties of CdS thin films grown by chemical bath deposition," Thin Solid Films, vol. 518, no. 4, pp. 1259-1262, 2009.
[49] R. Kirschman, High-Temperature Electronics, IEEE Press, New York, NY, USA, 1999.

[50] S. Kasap and P. Capper, Springer Handbook of Electronic and Photonic Materials, Springer, 2006.

[51] P. Blood and J. W. Orton, The Electrical Characterization of Semiconductors: Majority Carriers and Electron States, Academic Press, London, UK, 1992.

[52] P. Krulevitch, A. P. Lee, P. B. Ramsey, J. C. Trevino, J. Hamilton, and M. A. Northrup, "Thin film shape memory alloy microactuators," Journal of Microelectromechanical Systems, vol. 5, no. 4, pp. 270-282, 1996.

[53] M. Singh, Y. K. Vijay, and I. P. Jain, "The effect of a sulfur layer on FeTi thin films obliquely deposited for hydrogen storage," International Journal of Hydrogen Energy, vol. 16, no. 2, pp. 101-104, 1991.

[54] F. Bakkaloğlu, H. İ. Karahan, H. Efeoğlu, M. Yıldırım, U. Çevik, and Y. K. Yoğurtçu, "Magnetic studies on electrodeposited $\mathrm{Cu}_{1-x} \mathrm{Co}_{x}$ alloy films," Journal of Magnetism and Magnetic Materials, vol. 190, no. 3, pp. 193-198, 1998.

[55] Y. Shuai, X. Ou, C. Wu et al., "Substrate effect on the resistive switching in $\mathrm{BiFeO}_{3}$ thin films," Journal of Applied Physics, vol. 111, Article ID 07D906, 2012. 

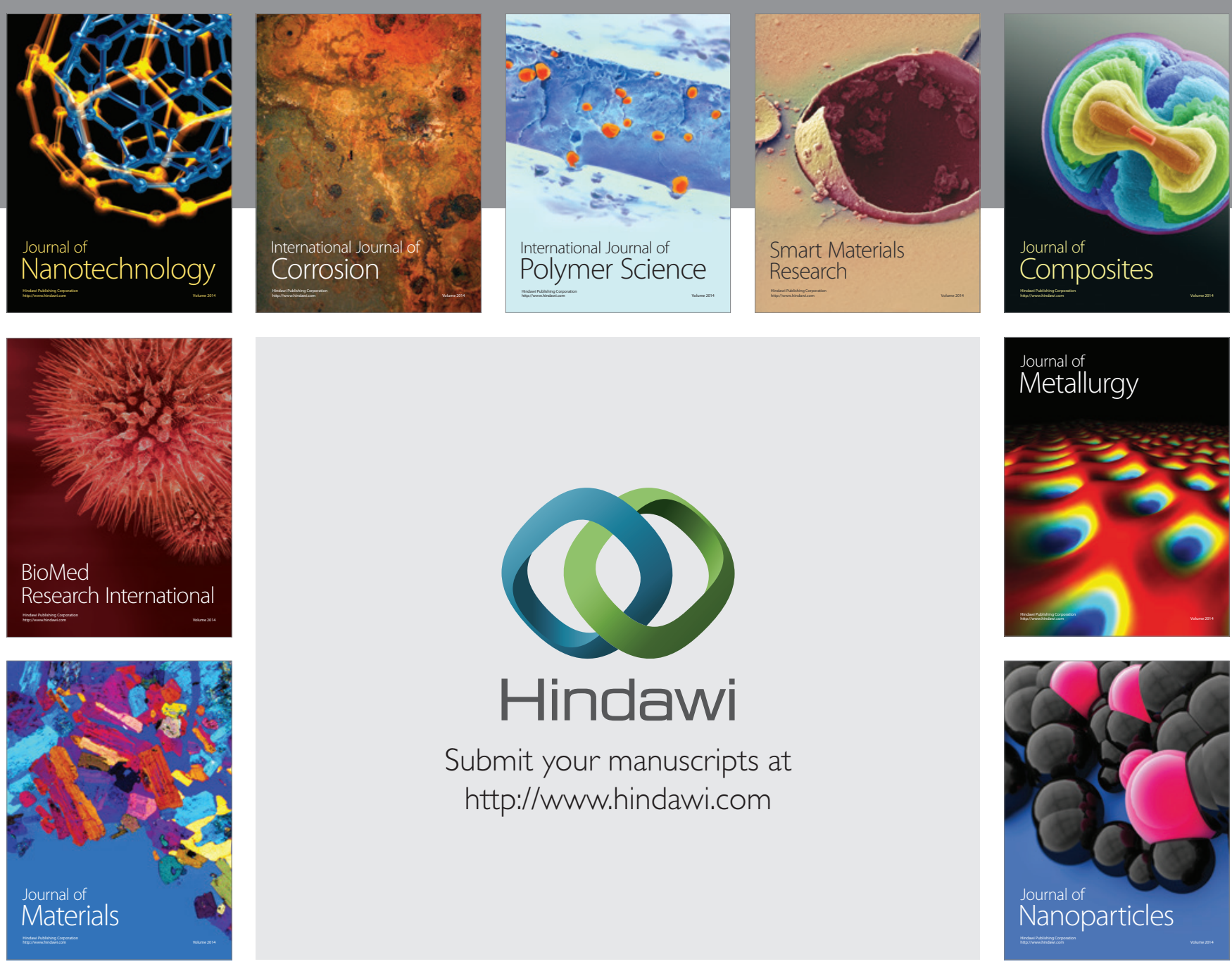

Submit your manuscripts at http://www.hindawi.com
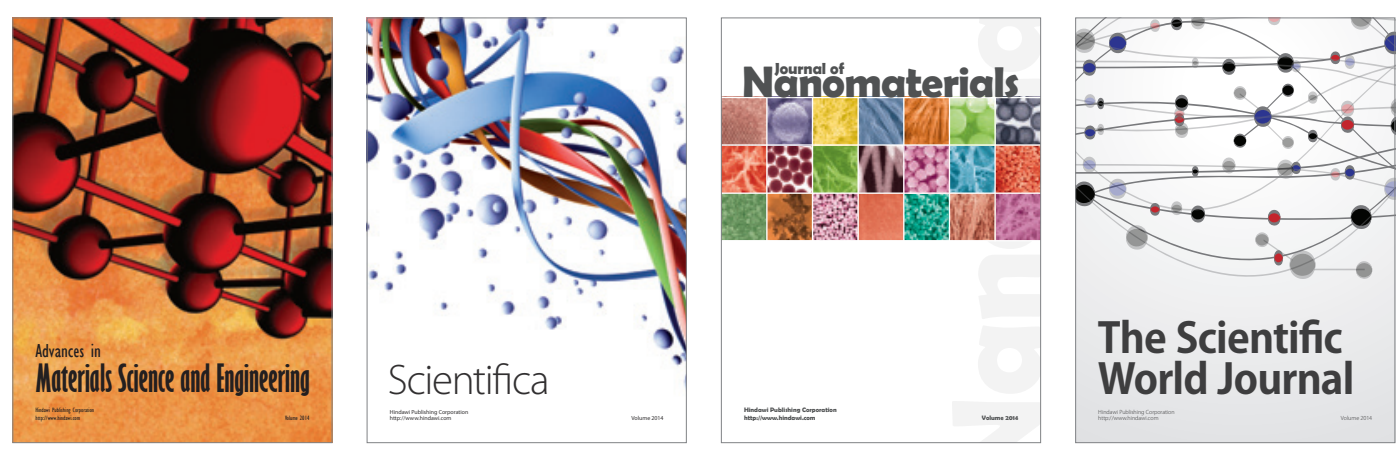

\section{The Scientific World Journal}
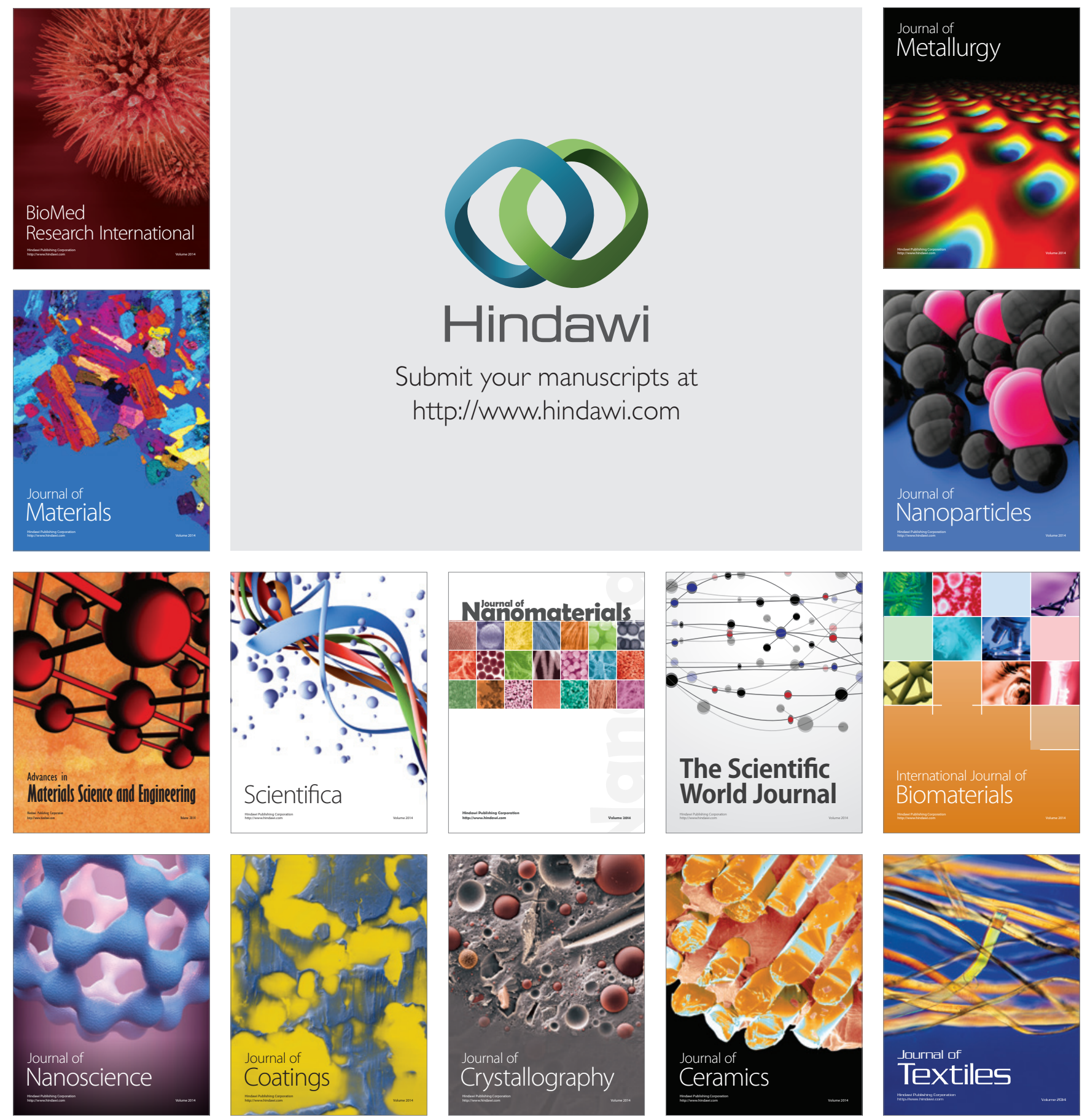